\title{
Evaporation of Fuel Film formed by an Impinging GDI Spray on a Hot Wall with High Surface Roughness
}

\author{
Yutaro KASUYA ${ }^{1}$, Yoshihiro KOBAYASHI*2, Masataka ARAI ${ }^{2}$ \\ ${ }^{1}$ Graduate school of Engineering, Tokyo Denki University, Tokyo Japan \\ ${ }^{2}$ Mechanical Engineering, Tokyo Denki University, Tokyo, Japan \\ ${ }^{*}$ Corresponding author email: ykoba@ms.dendai.ac.jp
}

\begin{abstract}
Formation and evaporation of fuel films on various surface roughness walls were investigated. Liquid fuel of iso-octane was injected from multi-hole injector of a DISI engine. Injected spray was impinged on an aluminium wall having low or high roughness $\left(R_{a}=1.07 \mu \mathrm{m}\right.$ to $\left.17.1 \mu \mathrm{m}\right)$ and fuel film-was formed on the wall. Wall surface temperature before fuel spray impingement was controlled by an electric heater $\left(25^{\circ} \mathrm{C}\right.$ to $\left.130^{\circ} \mathrm{C}\right)$. Fuel film behaviour with elapsed time under various wall conditions was captured by a high-speed camera. Fuel film spreading area change and evaporation lifetime of the fuel film were obtained from the captured top view image. As a result, it was found that the fuel film spreading area became narrower with an increase of the surface roughness. The evaporation lifetime of fuel film became shorter with an increase of the surface roughness.
\end{abstract}

\section{Keywords}

Gasoline fuel injection, Surface roughness, Fuel film, Spray impingement, Hot surface

\section{Introduction}

Direct injection spark ignition (DISI) engine can achieve higher thermal efficiency. However, it has several problems owing to unburned $\mathrm{HC}$ and particulate matter (PM) emissions [1][2]. In a DISI engine, mainly in a cold start, fuel spray impinged to the piston top and some of impinged fuel adhered. Then diffusion flame occurred near the fuel film and soot which is the main composition of PM was formed. So, reduction of fuel film on the piston top is necessary to reduce PM emission. Then to reduce PM emission from the engine, details of fuel film behaviour such as film spread, evaporation, and evaporation lifetime should be understood.

Many researches had investigated adhesion behaver of fuel spray. For example, Luo, et al. [3] had investigated the characteristics of fuel film adhesion under different injection pressures, injection periods and ambient temperatures in a constant high-pressure chamber. In their study, fuel film area and thickness were measured by Mie scatting and refractive index matching (RIM) technique. Schulz, et al. [4] had observed fuel film formation using laser induces fluorescence (LIF) technique. In addition, they investigated influence of parameters including ambient pressure, fuel temperature, injector-wall distance, and spray impingement angle on the fuel film formation. Jungst, et al. [5] had measured fuel film thickness and mass of fuel film adhered on an impingement wall of quartz glass. Using LIF and laser induced incandescence (LIF) technique, they observed $\mathrm{PAH}$ and soot formation from fuel film combustion.

Kollpe, et al. [6] had measured piston surface temperature in a GDI engine using a thinfilm thermocouple embedded piston. Furthermore, they investigated the influence of various parameters such as injection pressure and injection timing on detail temperature history of piston top. Using a thin film thermocouple, Kuboyama, et al. [7] had investigated heat transfer between impinging fuel spray and piston top. They reported that heat flux between the wall and the impinging fuel spray increased with an increase of wall temperature.

As for the relationship between fuel film and impingement wall, Komuro et al. [8] had observed detailed fuel film behaviour on various walls having different levels of surface roughness and thermal conductivity. They reported that the evaporation lifetime of fuel film became shorter with an increase of the surface roughness. To reduce the heat loss from combustion gas to piston, Wakisaka et al. [9] had studied the influence of Silica Reinforced Porous Anodized Aluminium (SiRPA) coating. They reported that the piston top with smooth 
surface reduced fuel film adhesion. Recently, there is a patent that reduces heat loss from combustion gas to the piston by decreasing surface roughness of the piston top. [10]

However, there are a few studies to reveal the relationship between surface roughness and adhesion behaviour of a fuel spray. During injection period, fuel spray injected from injector impinged to a wall and then fuel film spread along the wall surface. It is considered that spreading of fuel film was affected by surface roughness of the wall. Furthermore, with an increase of the surface roughness, substantial contact area between the fuel film and wall surface became increasing. Therefore, it is considered that evaporation lifetime of fuel film was changed by surface roughness. Thus, to clarify the relationship between fuel film behaviour and surface roughness is important for understanding of the heat loss mechanism.

In this study, fuel film behaviour on various walls with different levels of surface roughness were investigated. Here, various aluminium plates $\left(R_{a}=1.07 \mu \mathrm{m}\right.$ to $\left.17.7 \mu \mathrm{m}\right)$ were used as impingement wall surfaces instead of piston top surface. Fuel spray impingement and fuel film formation phenomena were captured by a high-speed camera. Fuel film area change and evaporation lifetime of the fuel film were obtained from captured images with additional data processing.

\section{Experimental set up}

Experimental set up used in this study is shown in Fig. 1. It consisted of a fuel tank, a multihole DISI injector (16450-5A2A01, DENSO), an injection control unit, and an impingement wall. Iso-octane was used as a test fuel. It was pressurized by $\mathrm{N}_{2}$ gas and then injected from the DISI injector. The injector was set in perpendicular to the wall. The distance from the injector to the wall was $30 \mathrm{~mm}$. Fuel spray impingement and fuel film formation with elapsed time were captured by a high-speed camera (MERECAM GX-8F, NAC image Technology) set $30^{\circ}$ angle to the impingement wall.

Experimental conditions are listed in Table 1. To imitate injection condition in actual DISI engine, pressure $P_{i n j}$ and period $t_{i n j}$ of the injection were set at 10MPs and $1.5 \mathrm{~ms}$ (Fuel injection mass is $14 \mathrm{mg}$ ), respectively. Aluminum plates were used as impingement walls and their surface roughness $R_{a}$ was changed from $1.07 \mu \mathrm{m}$ to $17.7 \mu \mathrm{m}$. All experiments were carried out in atmospheric pressure and room temperature condition, but impingement wall temperature was changed. Wall surface temperature before spray impingement was controlled by an electric heater. Initial temperature at center of the wall surface $T_{0}$ was set at $25^{\circ} \mathrm{C}-130^{\circ} \mathrm{C}$. The surface temperature changes by spray impingement during spray impingement was reported by Komuro et al. [8]

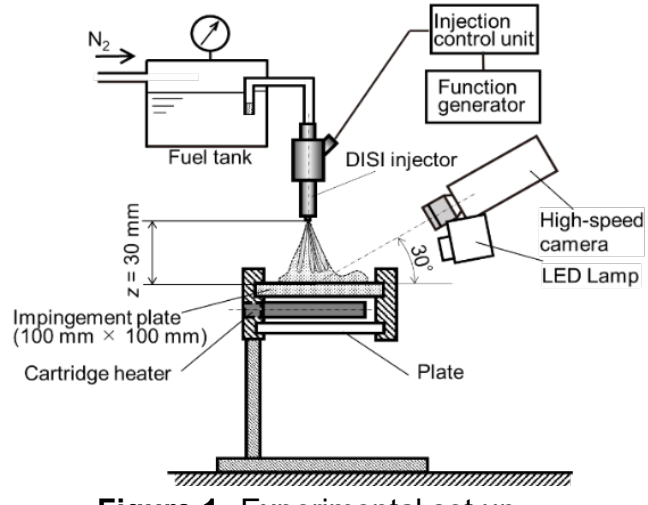

Figure 1. Experimental set up

Table 1. Experimental conditions

\begin{tabular}{|l|l|}
\hline Test fuel & Iso-octane \\
\hline Inpingement angle & $90^{\circ}$ \\
\hline Distance between injector and wall Z mm & 30 \\
\hline Ambient pressure $P_{a} \mathrm{MPa}$ & 0.1 \\
\hline Injection pressure $P_{i n j} \mathrm{MPa}$ & 10 \\
\hline Injection priod $t_{i n j} \mathrm{~ms}$ & 1.5 \\
\hline Injection mass $M_{i n j} \mathrm{mg}$ & 14 \\
\hline Plate material & Aluminum \\
\hline Plate surface roughness $R_{a} \mu \mathrm{m}$ & $1.07,2.22,2.77,3.71,5.96$, \\
\hline Initial wall surface temperature $T_{0}{ }^{\circ} \mathrm{C}$ & $6.74,7.27,8.30,17.1$ \\
\hline
\end{tabular}

The injector tip, impingement sprays observed from two different directions, and the coordinate system used in this study are shown in Fig. 2. The injector had 6 holes and counterbore diameter of injection hole was approximately $0.2 \mathrm{~mm}$. The origin of the coordinate system was set on the wall and its position was directly below the injector. The impingement footprint of the fuel spray injected from the DISI injector showed a triangle pattern, then $X$ and $Y$ axes were defined as indicated in Fig. 2. 


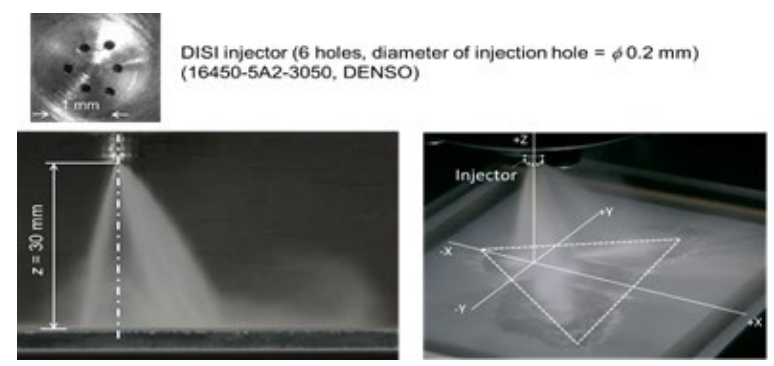

Figure 2. Injector tip and wall impingement spray

\section{Measurement of fuel film area}

In our previous study [4], we measured fuel film area using a bottom view captured though ground quartz glass. In this study, an aluminium plate was used as the impingement plate so a fuel film image could only be captured from the top sideway direction. Therefore, as shown in Fig. 3 (a), the captured image was an inclined image and it was hard to be analysed. Then this image was converted to the normal direction image by computer processing as shown in Fig. 3 (b) and fuel film area was measured using the converted image.

Measurement accuracy of this method was checked by bottom view and converted top view images. To obtain bottom and top images, a ground quartz glass plate was used. A bottom view image of the fuel film was captured first by a high-speed camera, then an inclined top view image of the same condition was captured using the same camera. Images for the maximum fuel film area at different timings were used for comparison. In Figure 4, the maximum fuel areas of both images under various wall temperature conditions resulted in good agreement. It means the adequateness of this image conversion method.

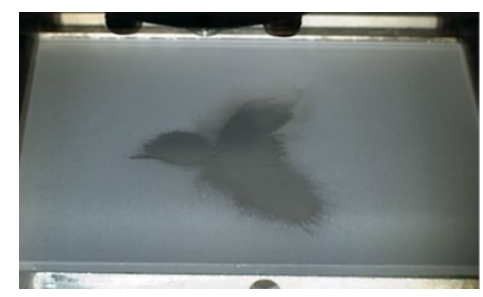

(a) Direct photo

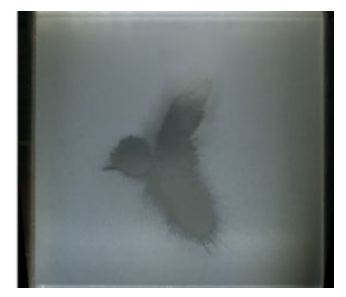

(b) After conversion

Figure 3. Top view image before and after conversion

\section{Observation of fuel film}

Temporal relationship between spray behaviour and elapsed time is indicated in Fig. 5. Although the figure shows fuel film behaviour until $t=31.5 \mathrm{~ms}$, fuel film observation was continued after $t=31.5 \mathrm{~ms}$. Here, fuel injection started at $t=0 \mathrm{~ms}$ and wall impingement of fuel spray started at $t=0.5 \mathrm{~ms}$. The fuel injection continued until $t=1.5 \mathrm{~ms}$, and the fuel spray impingement ended at $t=2.0 \mathrm{~ms}$. In addition to the time chart, top view images at typical timings are shown above the chart. The timings of images are impingement start $(t=0.5 \mathrm{~ms})$, before injection end ( $t=1.4 \mathrm{~ms})$, just after impingement end $(t=3.0 \mathrm{~ms})$, and after impingement $(t=16.5 \mathrm{~ms}$ and $31.5 \mathrm{~ms}$ ). Generally, fuel film spread to $+X$ direction and little spreading occurred in $-X$ direction. As for the lateral $Y$ direction, the fuel film area was spreading with keeping the triangle pattern shown in Fig. 3 and dense film spots were remained at every corner of the triangle fuel film.

Images of fuel spray during impingement and fuel film after impingement under various temperature and surface roughness conditions are shown in Figs. 6 - 9. In every figure, images corresponding to four levels of wall roughness $(R a=1.07 \mu \mathrm{m}, R a=3.71 \mu \mathrm{m}, R a=6.74 \mu \mathrm{m}$, and $R a=17.1 \mu \mathrm{m}$ ) were summarized.

Figure 6 shows fuel film formation under $T_{0}=25^{\circ} \mathrm{C}$. In $R a=1.07 \mu \mathrm{m}$ images displayed in the top row, fuel spray impinging to the wall and fuel film on the wall surface at $t=1.0 \mathrm{~ms}$ are shown in the second column. The third column and forth column of the images correspond to $t=1.4 \mathrm{~ms}$ (during impingement) and $t=3.0 \mathrm{~ms}$ (just after impingement end), respectively. Since the fuel film area after the injection end $(t=3.0 \mathrm{~ms})$ was wider than before the injection end $(t=1.4 \mathrm{~ms})$, it was concluded that the fuel film was still spreading even after the end of 
impingement. At $t=16.5 \mathrm{~ms}$, a wavy surface on the fuel film was observed near the periphery of fuel film. It suggested that a thin fuel film was formed inside the periphery. Further, most portions of the fuel film still remained at $t=31.5 \mathrm{~ms}$.

In the second row images relevant to $R a=3.71 \mu \mathrm{m}$, fuel film was also formed during spray impingement as like as $R a=1.07 \mu \mathrm{m}$ condition. The fuel film spreading continued after the spray impingement end. However, the fuel film in this roughness condition did not spread wider than the case of Ra $1.07 \mu \mathrm{m}$. In the third row images of $R a=6.79 \mu \mathrm{m}$, fuel film was narrower than $R a=3.71 \mu \mathrm{m}$. As for the $R a=17.1 \mu \mathrm{m}$ images in the bottom low, spreading behaviour of the fuel film after the impingement end was not observed. Further, fuel film area was obviously narrower than that of $R a=1.07 \mu \mathrm{m}$. It was considered that fuel film spreading was prevented by rough surface.

Fuel film formation under $T_{0}=100^{\circ} \mathrm{C}$ is shown in Fig. 7. Enlarged image of the fuel film on $R a=1.07 \mu \mathrm{m}$ surface at $t=31.5 \mathrm{~ms}$ is shown in Fig. 8 . In the top row images of $R a=1.07 \mu \mathrm{m}$ (Fig. 7), wall impingement spray and fuel film formed after impingement were also observed though high temperature $\left(100^{\circ} \mathrm{C}\right)$ conditions. Additionally, as shown in Fig. 8, it was observed that most portions of the fuel film were bubbling. Since the wall surface temperature was high and near boiling temperature of iso-octane, it was considered that nucleate boiling occurred after impingement.

In $R a=3.71 \mu \mathrm{m}$ images, fuel film after impingement was narrower than $R a=1.07 \mu \mathrm{m}$. Furthermore, at $t=16.5 \mathrm{~ms}$, dry-up area was observed in some portions of the fuel film. It means that most of the fuel film evaporated before $t=31.5 \mathrm{~ms}$. As for $R a=6.74$ images in the third row, the fuel film formation process was almost similar to the case of $R a=3.71 \mu \mathrm{m}$. However, the most of fuel film at $t=31.5 \mathrm{~ms}$ evaporated more clearly than on the $R a=3.71$ $\mu \mathrm{m}$ wall. In $R a=17.1 \mu \mathrm{m}$, no fuel film was observed after impingement. It was considered that the fuel film evaporation completed immediately after the end of the spray film impingement.

Fuel film formation under $T_{0}=130^{\circ} \mathrm{C}$ is shown in Fig. 9. On the $R a=1.07 \mu \mathrm{m}$ wall, fuel film was observed just after the impingement. However, fuel film was not observed after $t=16.5$ $\mathrm{ms}$. On the $R a=3.71 \mu \mathrm{m}$ wall, whereas, fuel film adhered only around the footprint of the impingement spray. Further, at $t=3.0 \mathrm{~ms}$, fuel film area was obviously narrower than the fuel film area under $T_{0}=100^{\circ} \mathrm{C}$. After the impingement end, fuel film evaporated quickly before $t=$ $16.5 \mathrm{~ms}$. On the $R a=6.74 \mu \mathrm{m}$ wall, almost of the fuel film had already evaporated at $t=3.0$ $\mathrm{ms}$ and no fuel film was observed after $t=16.5 \mathrm{~ms}$. It was considered that owing to the higher temperature than the highest evaporation rate point of iso-octane droplet on a smooth surface [11], and owing the rough surface and wall temperature drop during the impingement, the fuel film rapidly evaporated after the end of fuel spray impingement.

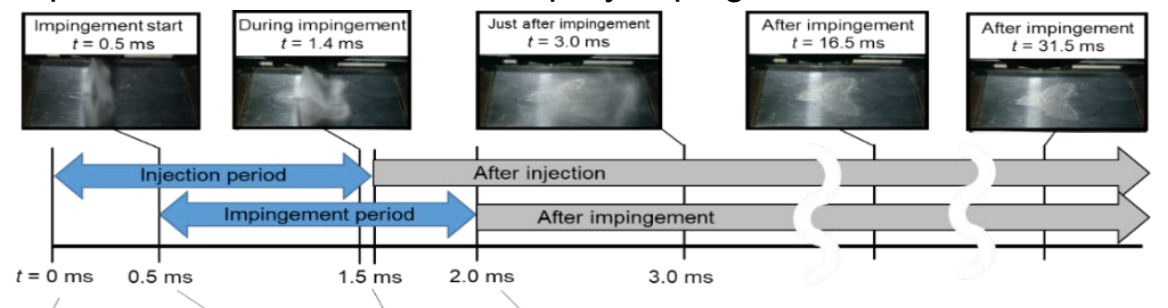

Injection start Impingement start Injection end Impingement end

Figure 5. Relationships among injection start, injection end, impingement start on the wall, and impingement end

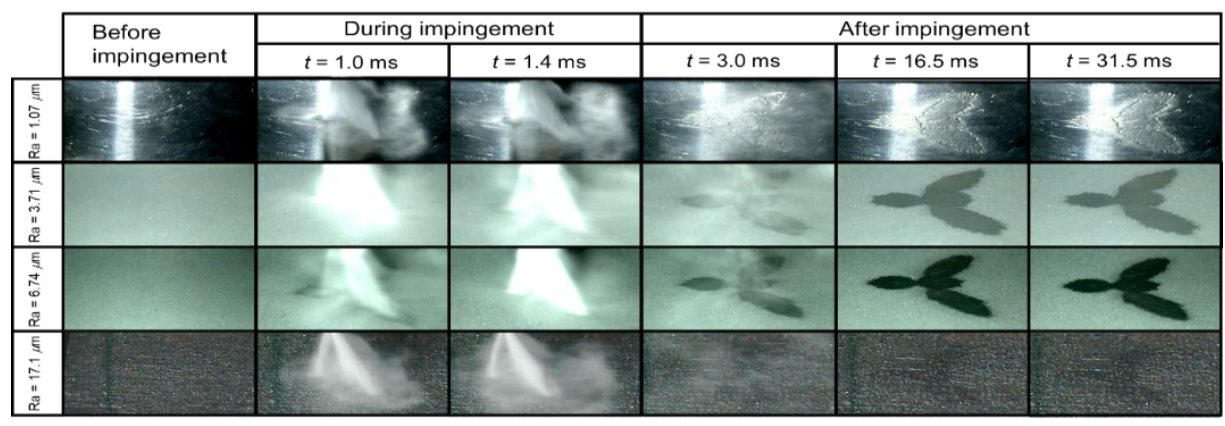

Figure. 6. Fuel film formation $\left(T_{0}=25^{\circ} \mathrm{C}\right)$ 


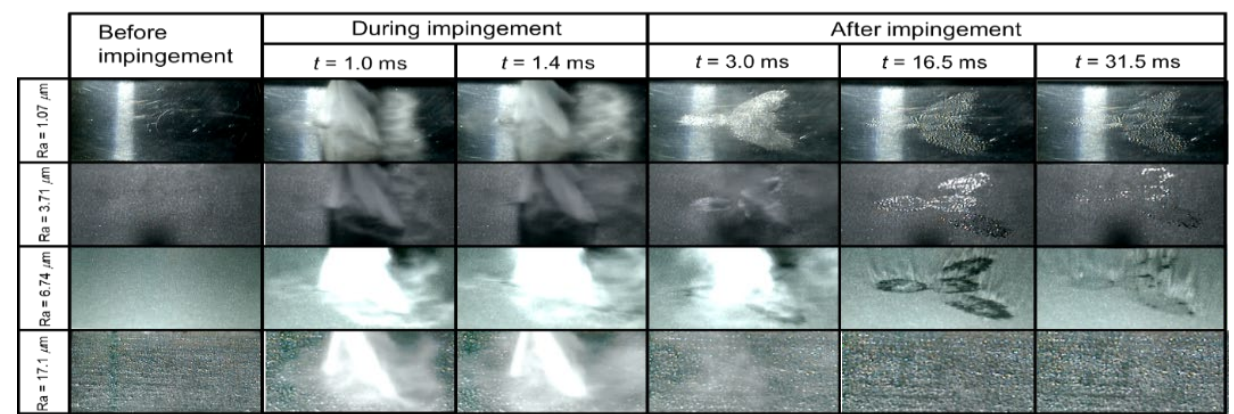

Figure 7. Fuel film formation $\left(T_{0}=100^{\circ} \mathrm{C}\right)$

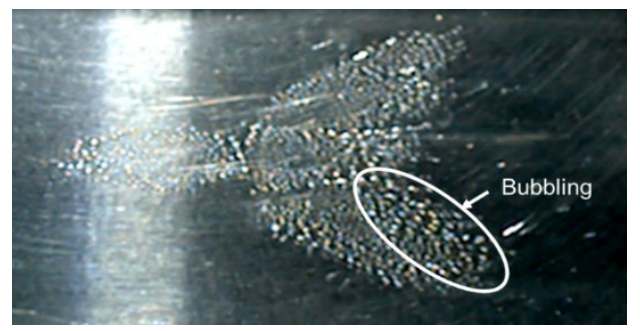

Figure 8. Fuel film on $R a=1.07 \mu \mathrm{m}$ surface at $t=31.5 \mathrm{~ms}\left(T_{0}=100^{\circ} \mathrm{C}\right)$

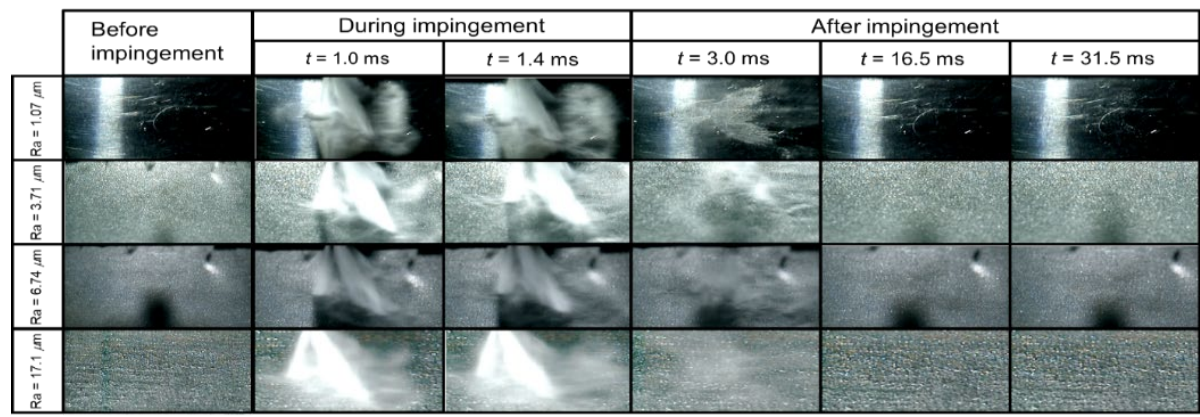

Figure 9. Fuel film formation $\left(T_{0}=130^{\circ} \mathrm{C}\right)$

\section{Fuel film area change with elapsed time}

The fuel film area change with elapsed time was investigated using the converted top view images. Since the fuel spray overlapped with the fuel film on the wall, details of the fuel film could not be observed during fuel injection period. So, the measurement of fuel film was performed on the images obtained after $t=3.0 \mathrm{~ms}$. Fuel film area changes with elapsed time under various wall temperature conditions are shown in Figs. $10-12$. The effect of surface roughness on fuel film could be observed in all figures and its effect was obvious in high temperature conditions.

Fuel film area change with elapsed time under $T_{0}=25^{\circ} \mathrm{C}$ condition is shown in Fig. 10 . Fuel film area on the $R a=1.07 \mu \mathrm{m}$ surface increased after the impingement end and kept increasing until $t=6 \mathrm{~ms}$. After then, it became constant. When the impinged fuel did not move from the impingement position, fuel film area consisted with impingement area and this situation might happen on the high roughness wall. It means that impingement area was around $750 \mathrm{~mm}^{2}$. On the low roughness wall such as $R a=1.07 \mu \mathrm{m}$, however, spreading motion already started during the impingement period and the film area at the end of impingement was wider than impingement area. As for $R a=3.71 \mu \mathrm{m}$ and $R a=6.74 \mu \mathrm{m}$ images, fuel film area increased as same as the $R a=1.07 \mu \mathrm{m}$ image until $t=6 \mathrm{~ms}$. However, fuel film area was narrower than $R a=1.07 \mu \mathrm{m}$. As for the $R a=17.1 \mu \mathrm{m}$ images, fuel film area decreased gradually until $t=10 \mathrm{~ms}$. Then fuel area became constant. Its area was narrower than other conditions.

Evaporation effect of the fuel film did not appear under low wall temperature but it clearly appeared under high wall temperature conditions. Figure 11 shows fuel film area change in $T_{0}$ $=100^{\circ} \mathrm{C}$ condition. Here, the fuel film area change for $R a=17.1 \mu \mathrm{m}$ is not shown in the figure, because no fuel film was observed after impingement. In all conditions, fuel film area increased after impingement. Then it was reduced due to evaporation. However, detail change of fuel 
film area shows the following roughness dependence. In the $R a=3.71 \mu \mathrm{m}$ condition, fuel film area at the impingement end was already smaller than the supposed impingement area. It means that fuel film evaporation might started before the impingement end. Fuel film area increased after impingement. In this temperature and roughness condition, fuel film area took its maximum at around $t=12 \mathrm{~ms}$. However, the maximum fuel film area was narrower than that of $R a=1.07 \mu \mathrm{m}$ condition. After taking the maximum, almost of the fuel film was evaporated before $t=50 \mathrm{~ms}$. In the $R a=6.74 \mu \mathrm{m}$ condition, the maximum fuel film area was observed at $t=5 \mathrm{~ms}$ but it was narrower than other conditions. Further, the fuel film evaporated completely before $t=30 \mathrm{~ms}$. It was found that the fuel film evaporation became faster with $R_{a}$ increase.

Liquid film formation and evaporation on the wall of $T_{0}=130^{\circ} \mathrm{C}$ are shown in Fig. 12. The fuel film area in the $R a=17.1 \mu \mathrm{m}$ condition could not be measured because of quick evaporation during impingement period. Under $R a=1.07 \mu \mathrm{m}$ condition, the film area at the impingement end might consist with the impingement area. The maximum fuel film area was almost same as the area under $T_{0}=100^{\circ} \mathrm{C}$. However, the fuel film evaporation was faster than the evaporation under $T_{0}=100^{\circ} \mathrm{C}$. Its evaporation completed at $t=16 \mathrm{~ms}$. On the $R a=3.71$ $\mu \mathrm{m}$ wall, the fuel film area just after the impingement was obviously smaller than that of the impingement area $\left(750 \mathrm{~mm}^{2}\right)$, and narrower than $R a=1.07 \mu \mathrm{m}$. Moreover, the fuel film evaporated completely at around $t=8.0 \mathrm{~ms}$. As for the $R a=6.74 \mu \mathrm{m}$ condition, the fuel film area just after the impingement end was the smallest in this figure. Decreasing tendency of fuel film area with elapsed time was the steepest. The fuel film evaporated completely at $t=5$ ms. It was considered that a fuel film on the rough surface evaporated faster than that on the smooth surface. In other words, the maximum fuel film area decreased with $R a$ increase.

Relationships between the maximum fuel film area and the initial wall temperature were summarized in Fig. 13. The maximum film area decreased with the surface roughness increase. On $R a=1.07 \mu \mathrm{m}$ roughness wall, the maximum of fuel film area under $T_{0}<75^{\circ} \mathrm{C}$ was almost constant but its maximum under $75^{\circ} \mathrm{C}<T_{0}$ decreased with an increase of $T_{0}$. In $R a=3.71 \mu \mathrm{m}$ and $R a=6.74 \mu \mathrm{m}$ roughness conditions, the maximum of fuel film area under $50^{\circ} \mathrm{C}<T_{0}$ decreased with an increase of initial wall temperature. On $R a=17.1 \mu \mathrm{m}$ wall, the fuel film area did not take the maximum and decreased monotonously with an increase of $T_{0}$.

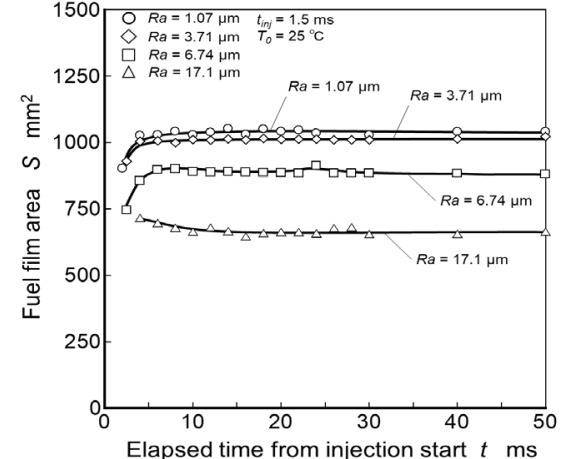

Figure 10. Fuel film area change with elapsed

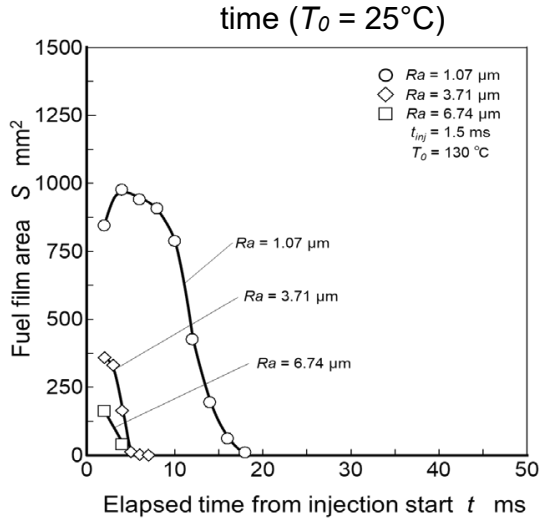

Figure 12. Fuel film area change with elapsed time $\left(T_{0}=130^{\circ} \mathrm{C}\right)$

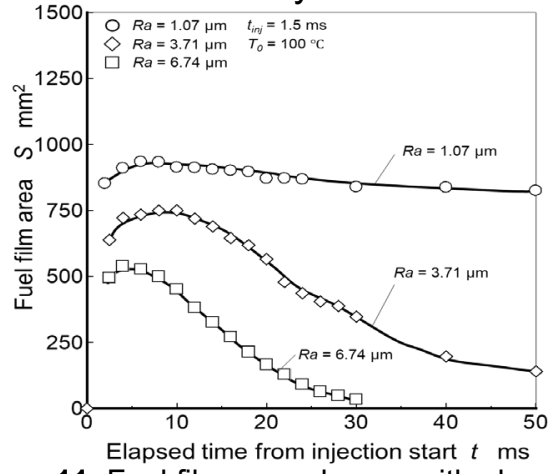

Figure 11. Fuel film area change with elapsed

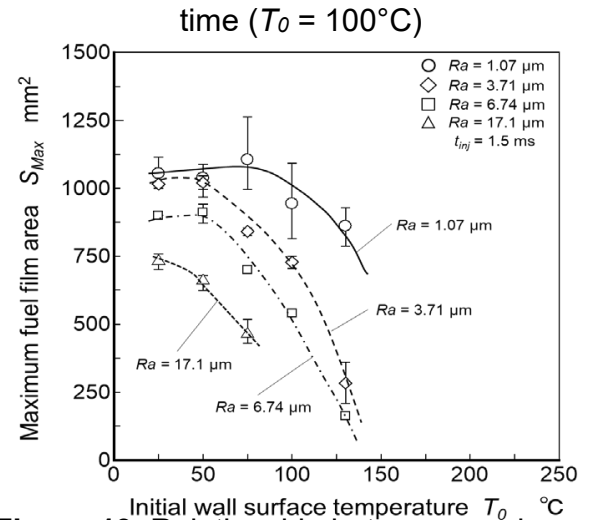

Figure 13. Relationship between maximum fuel film area and surface roughness 


\section{Surface roughness and evaporation lifetime of fuel film}

Relationship between surface roughness and evaporation lifetime of fuel film is shown in Fig. 14. Under $T_{0}=25^{\circ} \mathrm{C}$, the lifetime was almost constant regardless of the surface roughness, and it was approximately 15 seconds under various $R a$ conditions. When the wall temperature increased from room temperature to high temperature such as $50^{\circ} \mathrm{C}$, the evaporation lifetime was shortened by heat transfer from the wall. Under wall temperature condition below the boiling temperature of iso-octane such as $25^{\circ} \mathrm{C}, 50^{\circ} \mathrm{C}$ and $75^{\circ} \mathrm{C}$, changing of surface roughness levels has negligible effect on lifetime of the fuel film. However, with $T_{0}$ raise above its boiling temperature, the $R a$ dependence behavior of the lifetime became remarkable.

The lifetime became shorter with an increase of the wall surface temperature and an increase of the surface roughness. It was confirmed that the lifetime of fuel film was affected by wall surface roughness. Decreasing tendency of the lifetime with $R_{a}$ increase was clearly indicated in high surface roughness conditions. Further, at $T_{0}=130^{\circ} \mathrm{C}$, decreasing tendency of the lifetime was remarkable. Rapid decreasing of the lifetime was observed in the surface roughness levels of $1.07 \mu \mathrm{m}<R_{a}<3.71 \mu \mathrm{m}$. In our previous study [12], the mean thickness of the fuel film on the wall surface with various $R_{a}$ conditions were estimated and it was reported that fuel film thickness became slightly thicker with an increase of the surface roughness (fuel film thickness was approximately $14-20 \mu \mathrm{m}$ ). In general, substantial contact area including unevenness between wall surface and the fuel film is larger than projected area. Further, its contact area increases with an increase of surface roughness. Therefore, on a rough surface wall, it was considered that heat transfer from the wall to the fuel film increased owing to an increase of a substantial contact area between the wall surface and the fuel film. Thus, the lifetime of fuel film on hot surface decreased with an increase of the surface roughness. On $R_{a}>3.71 \mu \mathrm{m}$, increasing of surface roughness levels has few effects on the lifetime of fuel film. It might be caused the fuel film thickness and $R_{a}$ on rough surface were similar level.

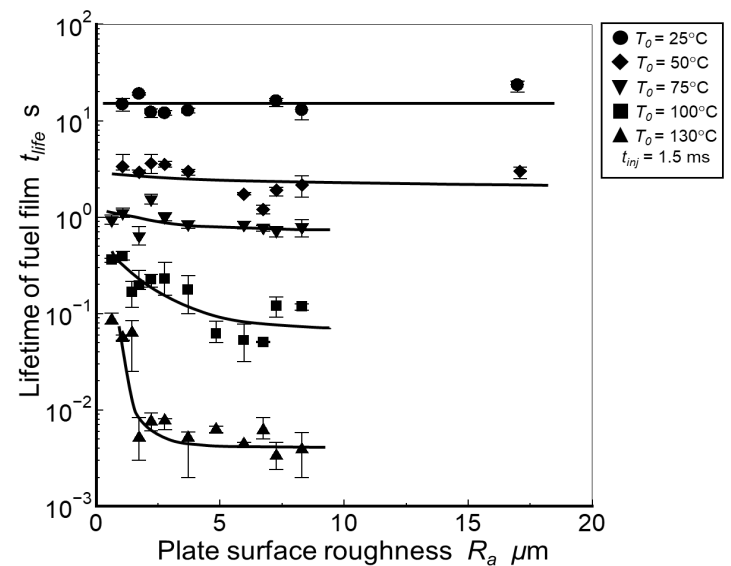

Figure 14. Relationship between surface roughness and lifetime of fuel film

\section{Conclusions}

Spreading of fuel film formed by wall impingement of iso-octane spray and its film evaporation on various surface roughness walls were investigated. Main results were summarized as follows:

(1) Spreading of the fuel film continued after impingement end. It was obvious on low roughness wall under low temperature.

(2) In high wall temperature condition, fuel film area at the impingement end was smaller than the impingement area supposed by the pattern of spray impingement. It took the maximum and then decreased owing to the evaporation. 
(3) Spreading behaviour of fuel film was restricted by the surface roughness of the wall. The fuel film area on the high roughness wall was narrower than on the low roughness wall.

(4) Evaporation lifetime of the fuel film decreased rapidly with temperature increase from $25^{\circ} \mathrm{C}$ to $130^{\circ} \mathrm{C}$.

(5) In the hot surface, the evaporation lifetime of the fuel film become shorter with an increase of surface roughness. Its decreasing tendency was remarkable in high temperature condition such as $130^{\circ} \mathrm{C}$.

\section{References}

[1] Ketter J. and Cheng, W., 2014, SAE Int. J. Engines, On the Nature of particulate Emissions from DISI Engines at Cold-Fast-Idol, 7(2):986-994.

[2] W. Jonathan, M. Sebastian, K. Markus, W. Hao, C. Nick, 2011, Proceedings of the Combustion Institute, Modelling soot formation in a DISI engine, 33 pp.3159-3167.

[3] H. Luo, K. Nishida, Y. Ogata, W. Zhang, and T. Fujikawa., 2019, Fuel, Fuel adhesion characteristics under non-evaporation and evaporation conditions: Part 1-effect of injection pressure, 240 pp.317-325.

[4] Schulz, F., Beyrau, F., 2019, Fuel, The effect of operation parameters on the formation of fuel wall films as a basis for the reduction of engine emissions, pp. 375-384.

[5] Kollpe, F., Seboldt, D., Jochmann, P., Hettinger, A. et al., Experimental Investigation of Fuel Impingement and Spray-Cooling on the Piston of a GDI Engine via Instantaneous Surface Temperature Measurements, SAE Int. J. Engines 7(3):1178-1194, 2014.

[6] Jungst, N., Kaiser, S.A., 2020, Combustion Institute, Visualization of soot formation from evaporation fuel films by laser-induced fluorescence and incandescence, pp.1-9

[7] T, Kuboyama., Y, Moriyoshi., J, Hashimmoto., Dec. 17-18. 2015, 26 th Annual conference on liquid Atomization and Spray Systems (ILASS-Japan), Measurement of local heat flux at spray impinging location in a $\mathrm{DI}$ gasoline engine, pp.94-97.

[8] Y. Komuro., Y, Kobayashi., M. Arai., 2019, 20th Annual Conference on Liquid Atomization and Spray Systems (ILASS), Fuel Film Formation and Wall Temperature Drop by Spray Impingement on a Wall.

[9] Y, Wakisaka., M, Inayoshi., K, Fukui., et al. 2017, R\&D review of Toyota CRDL, Vol.48, Challenges of Internal Combustion Engines for Achieving Low-carbon Society, No.4 pp19-30.

[10] H. Nagata, M. Uchida, Y. Watanabe: Piston. J. P. Patent 2018-112149, 2018-7-19.

[11] Z, Tamura., 1960, Hitachi review, Reserch of Evaporation and Combustion of a Drop Contacting with a Hot Surface, pp.75-80.

[12] Y. Kasuya., Y. KOBAYASHI., M. Arai., 2020, 21th Annual Conference on Liquid Atomization and Spray Systems (ILASS), Evaporation of Fuel Film Formed by an Impinging DGI Spray on a Hot Wall Characterized with Surface Roughness and Thrmal Conductivity.

\section{Contact}

Prof. Yoshihiro KOBAYASHI

Senju-Asahi-cho, Adachi-ku, Tokyo 120-8551, Japan.

Mechanical Engineering, Tokyo Denki University.

Email: ykoba@mail.dendai.ac.jp 